\title{
Colour Treatment of Aluminium Roof Sheets, a Significant Operating Factor
}

Pavel Kic, Miroslav Müller

Faculty of Engineering, Czech University of Life Sciences Prague. Kamycka 129, 16500 Praha 6-Suchdol. Czech Republic.E-mail: kic@tf.czu.cz, muller@tf.czu.cz.

\begin{abstract}
Aluminium roofing is used for low weight, good strength and weather resistance, easy handling and assembly, for various roofs of industrial and agricultural buildings, residential and family houses, holiday homes, garages and various shelters. Important is very long life, relatively low price and the possibility to choose the colour design according to your taste. The basic form is a natural unpainted finish, which can be used because the aluminium roofing material is not subject to corrosion and is chemically stable. The aim of this research is to verify a suitable method of measuring the colour of aluminium roofing and to determine the basic characteristic values of the most common colours of aluminium roofing sheets. The identification by the CIELAB system makes it possible to characterize the suitability of roofing sheets in terms of reducing the heat gains of the roof structure, thus complementing this very practical information to the RAL colour marking system. This leads to a reduction of the cooling demand of air of the building in the summer. In terms of colour measurement and evaluation, the classical method according to the CIELAB system is where the colour attributes lightness ( $L$-value), redness (a-value) and yellowness (b-value). These values may include the effect of surface gloss (SCI values) or exclusion (SCE values).
\end{abstract}

Keywords: Aluminium roof sheets, CIELAB, Colour measurement, Lightness, Surface roughness

\section{Introduction}

Aluminium roofing is a traditional roofing designed for various roofs of industrial and agricultural buildings, residential and family houses, holiday homes, garages and various shelters. It is very often used due to its low weight, strength and weather resistance, easy handling and assembly, various design options according to the type of roof, slope and easy adjustment even for very rugged roof shapes. Additional tinsmith elements are made from the same material. Very long life and relatively low price are important. The choice of colour according to individual taste plays a big role in the selection.

However, in addition to aesthetic aspects, the colour of the roof also has a great influence on some technical properties of the building. It is especially important in terms of thermal technical properties, especially in summer. It is mainly about the reflectance or absorption of solar radiation, which manifests itself in heat gains in the building. Many research and scientific studies are focused on these problems $[1,2,3,4,5]$. The necessary savings in electricity consumption for air-conditioning are increasingly leading to the use of passive air-conditioning systems, where the reduction of heat gains in buildings plays an important role. A suitable roof colour is very important in this respect. It is emphasized e.g. in scientific journal $[6,7,8,9]$, especially in relation to surface reflectance.

The roof surface can be also very significant from other perspectives. The scientific work [10] studies the influence of roof surface treatment on the quality of captured rainwater. From this research it shows that unlike some other materials, aluminium surface does not affect very negatively the water quality in terms of bacteriology. Effect of common rooftop materials as support base for solar disinfection (SODIS) in rural areas under temperate climates is studied in the article [11].

The basic form is a natural unpainted finish, which can be used because the aluminium roofing material is not subject to corrosion and is chemically stable. In the Czech Republic, the most widespread surface treatment of roof sheets, folded coverings and plumbing accessories is polyester varnish (PES). It has good UV and chemical resistance. Aluminium alloys belong among prospective materials and a research in various developing areas has performed at the present $[12,13,14,15]$.

Also polyvinyldenfluoride varnish (PVDF) and sometimes textural varnish (TEXTURA) are used for folded materials. Both of these materials also have good UV resistance and good chemical resistance. In addition, TEXTURA is characterized by good scratch resistance. In addition to the smooth surface, the surface may have an embossed finish (STUCCO).

In terms of colour measurement and evaluation, the classic method according to the CIELAB system is where the colour attributes lightness ( $\mathrm{L}^{*}$ value), redness $\left(\mathrm{a}^{*}\right.$ value) and yellowness ( $b^{*}$ value). These values may include the effect of surface gloss (SCI values) or exclusion (SCE values). The results of the measurements on sheet metal samples in this research should show in which cases two measured values are significantly different and for which colours two values are the same. The sampler results are compared with several roof sheets and the conformity between the sampler and the supplied roof sheets is verified. Roughness is an important property in terms of surface quality. Roughness measurement should show whether surface finish affects surface roughness.

The aim of this research is to verify a suitable method of measuring the colour of aluminium roofing and to determine the basic characteristic values of the most common colours of aluminium roofing sheets. The identification by the CIELAB system makes it possible to characterize the suitability of roofing sheets in terms of reducing the heat gains of the roof structure, thus complementing this very practical information to the RAL colour marking system. This leads to a reduction of the cooling demand of air of the building in the summer. 


\section{Material and Methods}

This research work and measurements were performed in the workshop at the Faculty of Engineering, Czech University of Life Sciences Prague. The aluminium roof sheets KERAFalc, which are manufactured as a one-sided painted aluminium alloy strip, coated with polyester paint (PES) and coated with protective PE foil on the face of the sheet, were measured. The reverse side of the sheet is provided with transparent varnish. STUCCO is a very interesting structured surface that highlights the advantages of roofing. Samples of the tested materials were 90 x $55 \mathrm{~mm}$ and thickness $0.7 \mathrm{mmm}$, smooth surface without texture, coated on one side.

The sample book of the company KERAMET was used (Fig. 1 A) in colours listed in Table 1. The comparison of the sampler with several roof sheets of $625 \mathrm{~mm}$ wide, $1000 \mathrm{~mm}$ long and $0.7 \mathrm{~mm}$ thick from the same company was also carried out in this research.

The colour was evaluated according to the CIELAB system where colour attributes lightness ( $\mathrm{L}^{*}$ value), redness ( $a^{*}$ value) and yellowness ( $b^{*}$ value) were measured five times of each fresh sample, after convection (natural or forced) drying and after hot air drying in $105^{\circ} \mathrm{C}$. The instrument used for this research, Spectrophotometer CM-600d Konica Minolta (Fig. 1 B), was first calibrated. Calibration is based on the black $\left(\mathrm{LO}={ }^{*}\right)$ and white $\left(\mathrm{L}^{*}\right.$ $=100$ ) standards. The results were processed and evaluated according to both methods: Specular Component Included (SCI) vs. Specular Component Excluded (SCE).

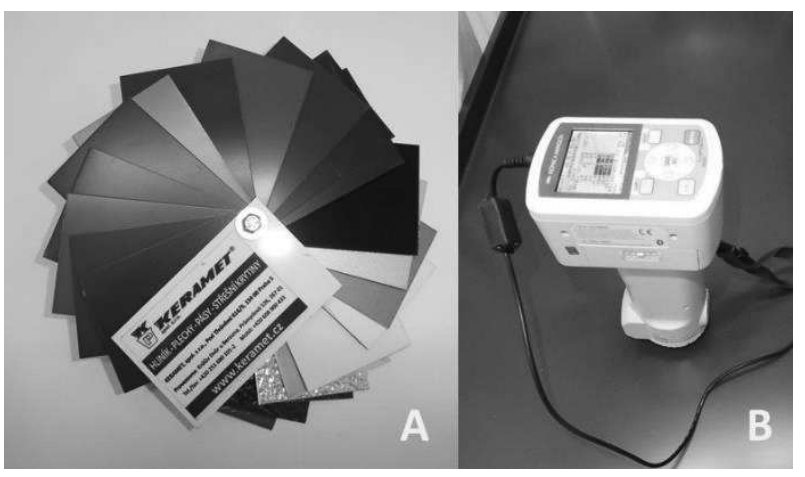

Fig. 1 Measurement procedure: A: Colour chart and methods of surface treatment of tested samples of Al roof sheets, B: Spectrophotometer CM-600d Konica Minolta

Tab. 1 Identification of tested material samples and their colour

\begin{tabular}{|c|c|c|}
\hline Marking of the sample & Colour & Measured sample \\
\hline RAL 3009 & Oxidized red & \\
\hline RAL 3011 & Reddish-brown & \\
\hline RAL 3016 & Coral red & \\
\hline RAL 5010 & Blue & \\
\hline RAL 6020 & Chrome green & \\
\hline RAL 7001 & Silver grey & \\
\hline RAL 7016 & Anthracite grey & \\
\hline RAL 7017 & Dark brown & \\
\hline RAL 8004 & Copper brown & \\
\hline RAL 8011 & Hazel brown & \\
\hline RAL 8017 & Chocolate brown & \\
\hline RAL 8016 & Mahogany brown & \\
\hline RAL 8019 & Grey-brown & \\
\hline RAL 9005 & Black & \\
\hline RAL 9006 & White aluminium & \\
\hline RAL 9007 & Grey aluminium & \\
\hline RAL $9010 \mathrm{M}$ & Matt pure white & \\
\hline RAL $9010 \mathrm{~L}$ & Gloss pure white & \\
\hline Basic aluminium material - smooth natural surface (marked AL) & Natural unpainted finish & \\
\hline Basic aluminium material - embossed natural surface (marked EMBOS) & EMBOS & Weisy \\
\hline RAL 8017 & Chocolate brown Stucco & \\
\hline RAL 7016 & Anthracite grey EMBOS & \\
\hline RAL 3016 & Coral red EMBOS & \\
\hline
\end{tabular}


The obtained results of colour range coordinates of tested samples were processed by Excel software and verified by statistical software Statistica 12 (ANOVA and TUKEY HSD Test) to recognise if the differences are significant. Different superscript letters $(a, b)$ in common measured variable are significantly different from each other (difference between the SCE and SCI values) in the table (ANOVA; Tukey HSD Test; $P \leq 0.05$ ), e.g. if there are the same superscript letters in the columns (the SCE and SCI values) it means the differences between the values of the same homogenous group are not statistically significant at the significance level of 0.05 .

Also the results of comparative measurements of real roof sheets with the samples were evaluated using statistical software Statistica 12 (ANOVA and TUKEY HSD Test) to recognize if the differences between the samples and the roof sheets are significant. It was measured at five locations of both samples and plates so that the uniformity of paint application could be assessed.

The surface roughness was measured on test samples by means of the contact profilometer Mitutoyo Surftest 301. Marginal cut-off was set as $2.5 \mathrm{~mm}$ x 5. Marginal cut-off $2.5 \mathrm{~mm}$ was chosen namely owing to a texture of the embossed surface of test samples, which showed huge inequalities comparing to the smooth surface. The roughness parameters $\mathrm{Ra}$ and $\mathrm{Rz}$ were measured on the surface.

Measured data were evaluated by means of the program STATISTICA - ANOVA F-test method, i.e. a hypothesis $\mathrm{H}_{0}$ presents a statistically insignificant difference among measured data $(\mathrm{p}>0.05)$ and a hypothesis $\mathrm{H}_{1}$ presents a rejection of the hypothesis $\mathrm{H}_{0}$, i.e. there is the statistically significant difference among measured data $(\mathrm{p}<$ $0.05)$.

\section{Results and Discussion}

Principal results of the CIELAB measurement are summarized and presented in Table 2. The results show the basic colour characteristics of the roof sheet assortment.

Tab. 2 Colour range coordinates ( $L$, $a$ and $b$ mean values with $S D)$ of tested samples. Different superscript letters ( $a, b)$ are sign of high significant difference (ANOVA; Tukey HSD Test; $P \leq 0.05$ ) between the SCE and SCI values.

\begin{tabular}{|c|c|c|c|c|c|c|}
\hline \multirow{2}{*}{ Tested samples } & \multicolumn{3}{|c|}{ SCE } & \multicolumn{3}{|c|}{ SCI } \\
\hline & $\mathrm{L}^{\star} \pm \mathrm{SD}$ & $\mathrm{a}^{\star} \pm \mathrm{SD}$ & $\mathrm{b}^{\star} \pm \mathrm{SD}$ & $\mathrm{L}^{\star} \pm \mathrm{SD}$ & $\mathrm{a}^{\star} \pm \mathrm{SD}$ & $\mathrm{b}^{\star} \pm \mathrm{SD}$ \\
\hline RAL 3009 & $27.9 \pm 0.1^{\mathrm{a}}$ & $20.4 \pm 0.1^{\mathrm{a}}$ & $12.5 \pm 0.1^{\mathrm{a}}$ & $34.8 \pm 0.2^{b}$ & $15.8 \pm 0.2^{b}$ & $8.7 \pm 0.1^{b}$ \\
\hline RAL 3011 & $28.8 \pm 0.1^{\mathrm{a}}$ & $36.2 \pm 0.2^{\mathrm{a}}$ & $18.9 \pm 0.3^{\mathrm{a}}$ & $34.9 \pm 0.2^{b}$ & $29.5 \pm 0.3^{b}$ & $13.0 \pm 0.3^{b}$ \\
\hline RAL 3016 & $38.5 \pm 0.1^{\mathrm{a}}$ & $32.1 \pm 0.1^{\mathrm{a}}$ & $25.7 \pm 0.3^{\mathrm{a}}$ & $43.5 \pm 0.2^{b}$ & $27.7 \pm 0.3^{\mathrm{b}}$ & $19.4 \pm 0.4^{\mathrm{b}}$ \\
\hline RAL 5010 & $31.5 \pm 0.0^{\mathrm{a}}$ & $-8.7 \pm 0.1^{\mathrm{a}}$ & $-35.3 \pm 0.1^{\mathrm{a}}$ & $37.7 \pm 0.1^{\mathrm{b}}$ & $-6.4 \pm 0.1^{b}$ & $-30.5 \pm 0.1^{b}$ \\
\hline RAL 6020 & $29.8 \pm 0.1^{\mathrm{a}}$ & $-6.8 \pm 0.1^{\mathrm{a}}$ & $7.6 \pm 0.1^{\mathrm{a}}$ & $35.9 \pm 0.1^{\mathrm{b}}$ & $-5.2 \pm 0.0^{\mathrm{b}}$ & $5.6 \pm 0.1^{\mathrm{b}}$ \\
\hline RAL 7001 & $55.6 \pm 0.1^{\mathrm{a}}$ & $-1.8 \pm 0.0^{\mathrm{a}}$ & $-2.2 \pm 0.1^{\mathrm{a}}$ & $58.5 \pm 0.1^{b}$ & $-1.6 \pm 0.0^{b}$ & $-2.1 \pm 0.1^{\mathrm{a}}$ \\
\hline RAL 7016 & $26.7 \pm 0.1^{\mathrm{a}}$ & $-1.1 \pm 0.0^{\mathrm{a}}$ & $-2.9 \pm 0.1^{\mathrm{a}}$ & $34.5 \pm 0.1^{\mathrm{b}}$ & $-0.7 \pm 0.2^{b}$ & $-2.3 \pm 0.1^{b}$ \\
\hline RAL 8004 & $36.9 \pm 8^{a}$ & $26.2 \pm 0.1^{\mathrm{a}}$ & $27.0 \pm 0.2^{\mathrm{a}}$ & $43.1 \pm 0.0^{\mathrm{b}}$ & $21.6 \pm 0.1^{\mathrm{b}}$ & $19.0 \pm 0.1^{\mathrm{b}}$ \\
\hline RAL 8011 & $29.1 \pm 0.1^{\mathrm{a}}$ & $12.1 \pm 0.1^{\mathrm{a}}$ & $14.0 \pm 0.1^{\mathrm{a}}$ & $36.0 \pm 0.1^{\mathrm{b}}$ & $9.3 \pm 0.0^{\mathrm{b}}$ & $9.6 \pm 0.1^{\mathrm{b}}$ \\
\hline RAL 8016 & $25.0 \pm 0.1^{\mathrm{a}}$ & $7.5 \pm 0.0^{\mathrm{a}}$ & $6.5 \pm 0.1^{\mathrm{a}}$ & $30.3 \pm 0.1^{\mathrm{b}}$ & $6.0 \pm 0.1^{b}$ & $5.1 \pm 0.1^{b}$ \\
\hline RAL 8019 & $25.6 \pm 0.1^{\mathrm{a}}$ & $2.3 \pm 0.0^{\mathrm{a}}$ & $1.3 \pm 0.0^{\mathrm{a}}$ & $31.8 \pm 0.0^{\mathrm{b}}$ & $1.8 \pm 0.0^{\mathrm{b}}$ & $0.7 \pm 0.0^{\mathrm{b}}$ \\
\hline RAL 9005 & $10.4 \pm 0.4^{\mathrm{a}}$ & $-0.1 \pm 0.1^{\mathrm{a}}$ & $-0.9 \pm 0.2^{\mathrm{a}}$ & $25.6 \pm 0.1^{\mathrm{b}}$ & $-0.1 \pm 0.0^{\mathrm{a}}$ & $-0.8 \pm 0.1^{\mathrm{a}}$ \\
\hline RAL 9006 & $75.8 \pm 0.1^{\mathrm{a}}$ & $-0.3 \pm 0.0^{\mathrm{a}}$ & $-0.6 \pm 0.1^{\mathrm{a}}$ & $79.2 \pm 0.2^{\mathrm{b}}$ & $-0.3 \pm 0.0^{\mathrm{a}}$ & $-0.6 \pm 0.1^{\mathrm{a}}$ \\
\hline RAL 9007 & $56.8 \pm 0.1^{\mathrm{a}}$ & $0.3 \pm 0.0^{\mathrm{a}}$ & $1.6 \pm 0.0^{\mathrm{a}}$ & $60.6 \pm 0.1^{b}$ & $0.3 \pm 0.0^{\mathrm{b}}$ & $1.4 \pm 0.0^{\mathrm{b}}$ \\
\hline RAL $9010 \mathrm{M}$ & $90.1 \pm 0.1^{\mathrm{a}}$ & $-1.5 \pm 0.0^{\mathrm{a}}$ & $1.1 \pm 0.3^{\mathrm{a}}$ & $91.6 \pm 0.1^{b}$ & $-1.4 \pm 0.0^{\mathrm{a}}$ & $1.0 \pm 0.3^{\mathrm{a}}$ \\
\hline RAL 9010 L & $89.9 \pm 0.1^{\mathrm{a}}$ & $-2.2 \pm 0.0^{\mathrm{a}}$ & $2.5 \pm 0.3^{\mathrm{a}}$ & $91.4 \pm 0.0^{\mathrm{b}}$ & $-2.1 \pm 0.0^{b}$ & $2.4 \pm 0.3^{\mathrm{a}}$ \\
\hline $\mathrm{AL}$ & $65.1 \pm 0.3^{\mathrm{a}}$ & $-0.4 \pm 0.0^{\mathrm{a}}$ & $-0.5 \pm 0.2^{\mathrm{a}}$ & $86.6 \pm 0.7^{b}$ & $0.1 \pm 0.1^{\mathrm{b}}$ & $2.1 \pm 0.3^{\mathrm{b}}$ \\
\hline EMBOS & $79.3 \pm 0.5^{\mathrm{a}}$ & $0.0 \pm 0.0^{\mathrm{a}}$ & $1.9 \pm 0.1^{\mathrm{a}}$ & $86.0 \pm 0.3^{b}$ & $0.2 \pm 0.0^{\mathrm{b}}$ & $2.8 \pm 0.1^{b}$ \\
\hline RAL 8017 Stucco & $31.2 \pm 0.6^{\mathrm{a}}$ & $5.3 \pm 0.2^{\mathrm{a}}$ & $3.3 \pm 0.2^{\mathrm{a}}$ & $34.1 \pm 0.2^{b}$ & $4.8 \pm 0.1^{b}$ & $2.7 \pm 0.0^{\mathrm{b}}$ \\
\hline RAL 7016 EMBOS & $32.9 \pm 0.2^{\mathrm{a}}$ & $-0.8 \pm 0.0^{\mathrm{a}}$ & $-2.6 \pm 0.0^{\mathrm{a}}$ & $35.4 \pm 0.1^{\mathrm{b}}$ & $-0.7 \pm 0.0^{\mathrm{b}}$ & $-2.5 \pm 0.0^{\mathrm{b}}$ \\
\hline RAL 3016 EMBOS & $40.6 \pm 0.1^{\mathrm{a}}$ & $29.6 \pm 0.2^{\mathrm{a}}$ & $22.3 \pm 0.3^{\mathrm{a}}$ & $43.9 \pm 0.1^{b}$ & $26.8 \pm 0.1^{\mathrm{b}}$ & $18.7 \pm 0.1^{\mathrm{b}}$ \\
\hline
\end{tabular}

SD - Standard deviation 
The results of lightness $\mathrm{L}^{*}$ indicate that the values SCI are slightly lighten than SCE by all types of measured samples, which is statistically significant. There are recognised also differences of colour shades, $a^{*}$ and $b^{*}$. Identical colours results were only in the case of samples: the greenness (a*) RAL 9005, RAL 9006 and RAL 9010 $\mathrm{M}$, and the yellowness (b*) RAL 7001, RAL 9005, RAL 9006, RAL $9010 \mathrm{M}$ and RAL $9010 \mathrm{~L}$. It is obvious and very interesting that the same results of SCE and SCI occur only in these cases of colours, which are Silver Grey, Black, White Aluminium, Matt Pure White and Gloss Pure White.

The obtained results allow to assemble a certain order of colours of the roofing plates in their ability to reflect solar radiation and thereby reduce the heat gain of the roof. RAL $9010 \mathrm{M}\left(\mathrm{L}^{*}=90.1 \pm 0.1\right)$ and RAL $9010 \mathrm{~L}$ $\left(\mathrm{L}^{*}=89.9 \pm 0.1\right)$ showed the best performance in this respect. In both cases, the SCE is high. The SCI values are even higher with RAL $9010 \mathrm{M}\left(\mathrm{L}^{*}=91.6 \pm 0.1\right)$ and RAL $9010 \mathrm{~L}\left(\mathrm{~L}^{*}=91.4 \pm 0.0\right)$. In contrast, the lowest lightness value was measured for black RAL $9005 \mathrm{SCE}\left(\mathrm{L}^{*}=10.4\right.$ $\pm 0.4)$ and SCI $\left(\mathrm{L}^{*}=25.6 \pm 0.1\right)$.

Relatively low lightness values in the range SCE values $\mathrm{L}^{*}$ from 25 to 41 were found (order by increasing lightness) for RAL 8016, 8019, 7016, 3009, 3011, 8011, 6020, 8017 Stucco, 5010, 7016 EMBOS, 8004, 3016 and 3016 EMBOS. Higher lightness values in the range SCE
$\mathrm{L}^{*}$ from 55 to 80 , according to which roof colours are more suitable for reducing heat gains, were measured for colours (order by increasing lightness) RAL 7001, 9007, AL, 9006 and EMBOS.

For further research in this area, the important benefit of this research is the accurate colour determination, which is not usually stated in the publications on this issue. E.g. the publication [8] only distinguishes between light colour, various colour and white. Only white, grey, black are defined in the publication [9].

The comparison of the measurement results of the samples and the whole roof sheets is given in Table 3 and Table 4. Standard deviation of all measured parameters are very small, that means the paint spraying was sufficiently uniform because no large deviations were found on the measured plates. Surprisingly the roof sheets with colours RAL 7016 and RAL 9006 were not identified as the same with parameters SCE and SCI in sampler. It could be explained by different batch of used paint spraying.

The RAL 3016 colour showed statistically identical SCE yellowness $\left(b^{*}\right)$ values between the sample and roof sheet as well as the SCI the greenness ( $\mathrm{a}^{*}$ ) and yellowness $\left(b^{*}\right)$. Natural unpainted finish Al roof sheet has the same SCI lightness L*. Statistically the same colour parameters as the sample was shown only by the roof sheet RAL 8017 Stucco.

Tab. 3 Comparison of colour range coordinates $S C E$ values (L, a and b mean values with $S D)$ of tested samples with roof sheets. Different superscript letters $(a, b)$ are sign of high significant difference (ANOVA; Tukey HSD Test; P $\leq 0.05$ ) between the SCE values of tested samples with roof sheets.

\begin{tabular}{|c|c|c|c|c|c|c|}
\hline \multirow{2}{*}{ Tested samples } & \multicolumn{3}{|c|}{ SCE samples } & \multicolumn{3}{c|}{ SCE roof sheets } \\
\cline { 2 - 7 } & $\mathrm{L}^{\star} \pm \mathrm{SD}$ & $\mathrm{a}^{\star} \pm \mathrm{SD}$ & $\mathrm{b}^{\star} \pm \mathrm{SD}$ & $\mathrm{L}^{\star} \pm \mathrm{SD}$ & $\mathrm{a}^{\star} \pm \mathrm{SD}$ & $\mathrm{b}^{\star} \pm \mathrm{SD}^{\mathrm{N}}$ \\
\hline RAL 3016 & $38.5 \pm 0.1^{\mathrm{a}}$ & $32.1 \pm 0.1^{\mathrm{a}}$ & $25.7 \pm 0.3^{\mathrm{a}}$ & $39.8 \pm 0.1^{\mathrm{b}}$ & $31.7 \pm 0.1^{\mathrm{b}}$ & $25.4 \pm 0.1^{\mathrm{a}}$ \\
\hline RAL 7016 & $26.7 \pm 0.1^{\mathrm{a}}$ & $-1.1 \pm 0.0^{\mathrm{a}}$ & $-2.9 \pm 0.1^{\mathrm{a}}$ & $25.5 \pm 0.1^{\mathrm{b}}$ & $-0.9 \pm 0.0^{\mathrm{b}}$ & $-1.4 \pm 0.0^{\mathrm{b}}$ \\
\hline RAL 9006 & $75.8 \pm 0.1^{\mathrm{a}}$ & $-0.3 \pm 0.0^{\mathrm{a}}$ & $-0.6 \pm 0.1^{\mathrm{a}}$ & $72.7 \pm 0.1^{\mathrm{b}}$ & $-0.7 \pm 0.0^{\mathrm{b}}$ & $-1.0 \pm 0.0^{\mathrm{b}}$ \\
\hline AL & $65.1 \pm 0.3^{\mathrm{a}}$ & $-0.4 \pm 0.0^{\mathrm{a}}$ & $-0.5 \pm 0.2^{\mathrm{a}}$ & $77.8 \pm 0.5^{\mathrm{b}}$ & $-0.5 \pm 0.0^{\mathrm{b}}$ & $-0.1 \pm 0.2^{\mathrm{b}}$ \\
\hline RAL 8017 Stucco & $31.2 \pm 0.6^{\mathrm{a}}$ & $5.3 \pm 0.2^{\mathrm{a}}$ & $3.3 \pm 0.2^{\mathrm{a}}$ & $31.1 \pm 0.1^{\mathrm{a}}$ & $5.4 \pm 0.1^{\mathrm{a}}$ & $3.2 \pm 0.1^{\mathrm{a}}$ \\
\hline
\end{tabular}

SD - Standard deviation

Tab. 4 Comparison of colour range coordinates SCI values ( $L$, a and $b$ mean values with $S D)$ of tested samples with roof sheets. Different superscript letters $(a, b)$ are sign of high significant difference (ANOVA; Tukey HSD Test; P $\leq 0.05$ ) between the SCI values of tested samples with roof sheets.

\begin{tabular}{|c|c|c|c|c|c|c|}
\hline \multirow{2}{*}{ Tested samples } & \multicolumn{3}{|c|}{ SCI samples } & \multicolumn{3}{c|}{ SCI roof sheets } \\
\cline { 2 - 7 } & $\mathrm{L}^{\star} \pm \mathrm{SD}$ & $\mathrm{a}^{\star} \pm \mathrm{SD}$ & $\mathrm{b}^{\star} \pm \mathrm{SD}$ & $\mathrm{L}^{\star} \pm \mathrm{SD}$ & $\mathrm{a}^{\star} \pm \mathrm{SD}$ & $\mathrm{b}^{\star} \pm \mathrm{SD}^{\mathrm{N}}$ \\
\hline RAL 3016 & $43.5 \pm 0.2^{\mathrm{a}}$ & $27.7 \pm 0.3^{\mathrm{a}}$ & $19.4 \pm 0.4^{\mathrm{a}}$ & $44.6 \pm 0.0^{\mathrm{b}}$ & $27.5 \pm 0.3^{\mathrm{a}}$ & $19.5 \pm 0.4^{\mathrm{a}}$ \\
\hline RAL 7016 & $34.5 \pm 0.1^{\mathrm{b}}$ & $-0.7 \pm 0.2^{\mathrm{b}}$ & $-2.3 \pm 0.1^{\mathrm{b}}$ & $34.5 \pm 0.1^{\mathrm{b}}$ & $-0.7 \pm 0.2^{\mathrm{a}}$ & $-2.3 \pm 0.1^{\mathrm{b}}$ \\
\hline RAL 9006 & $79.2 \pm 0.2^{\mathrm{b}}$ & $-0.3 \pm 0.0^{\mathrm{a}}$ & $-0.6 \pm 0.1^{\mathrm{a}}$ & $76.5 \pm 0.1^{\mathrm{b}}$ & $-0.6 \pm 0.0^{\mathrm{b}}$ & $-1.1 \pm 0.0^{\mathrm{b}}$ \\
\hline AL & $86.6 \pm 0.7^{\mathrm{a}}$ & $0.1 \pm 0.1^{\mathrm{a}}$ & $2.1 \pm 0.3^{\mathrm{a}}$ & $85.6 \pm 0.5^{\mathrm{a}}$ & $0.3 \pm 0.0^{\mathrm{b}}$ & $0.7 \pm 0.2^{\mathrm{b}}$ \\
\hline RAL 8017 Stucco & $34.1 \pm 0.2^{\mathrm{a}}$ & $4.8 \pm 0.1^{\mathrm{a}}$ & $2.7 \pm 0.0^{\mathrm{a}}$ & $34.1 \pm 0.1^{\mathrm{a}}$ & $4.8 \pm 0.1^{\mathrm{a}}$ & $2.7 \pm 0.1^{\mathrm{a}}$ \\
\hline
\end{tabular}

SD - Standard deviation 
Results of surface roughness measuring of embossed aluminium roof sheets $\mathrm{Ra}$ and $\mathrm{Rz}$ are visible in fig. 2 . The statistical evaluation proved significant differences in the results of the roughness parameter $\operatorname{Ra}(p=0.0071)$ in the significance level $\alpha 0.05$ on the surface of the embossed aluminium roof sheets depending on the colour tint. The statistical evaluation did not proved significant differences in the results of the roughness parameter $\mathrm{Rz}(\mathrm{p}=$ 0.1855 ) in the significance level $\alpha 0.05$ on the surface of the embossed aluminium roof sheets depending on the colour tint.

Results of roughness $\mathrm{Ra}$ and $\mathrm{Rz}$ measuring of the smooth surface of the aluminium roof sheets are visible in fig. 3. The statistical evaluation proved significant differences in the results of both roughness parameters $\mathrm{Ra}(\mathrm{p}$ $=0.0000)$ and $\mathrm{Rz}(\mathrm{p}=0.0000)$ in the significance level $\alpha$ 0.05 on the surface of the smooth aluminium roof sheets depending on the colour tint. It is obvious from the results that the colour tint influences also the resultant surface roughness, i.e. the parameters $\mathrm{Ra}$ and $\mathrm{Rz}$.

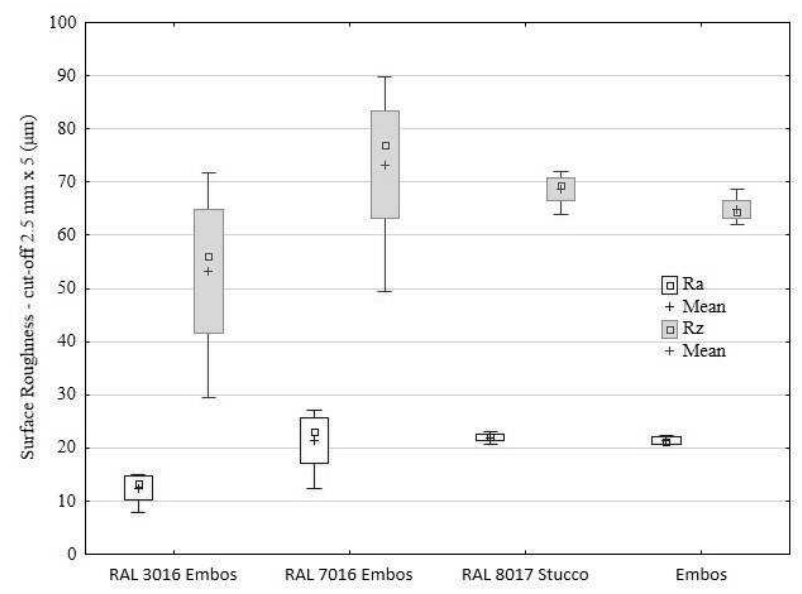

Fig. 2 Results of surface roughness measuring of aluminium roof sheets with embossed structure of surface

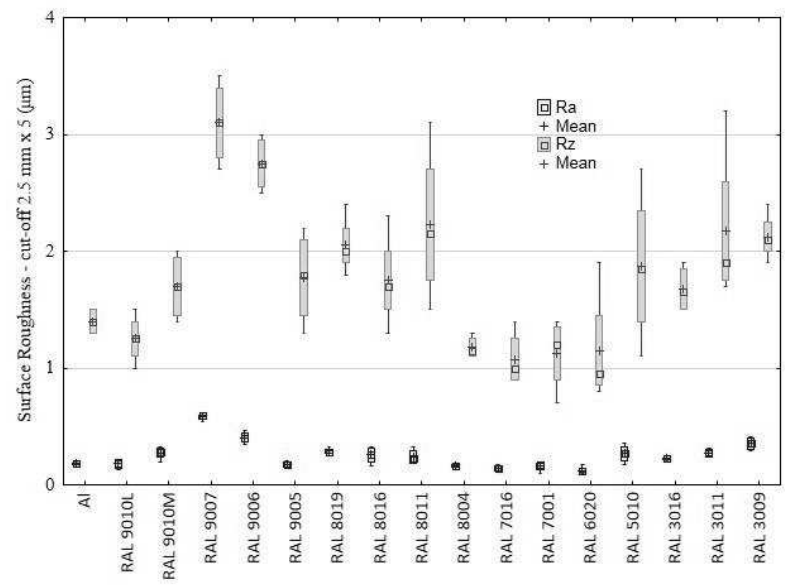

Fig. 3 Results of surface roughness measuring of aluminium roof sheets with smooth structure of surface

\section{Conclusions}

The colour spectrum of the aluminium roof sheets is marked according to the worldwide recognized designation according to RAL, which evaluates colour tints. The standardization of tints according to RAL is important for ensuring the same colour tint, which considerably influences an aesthetic character of a product. Colour tints influence also other factors, which play a significant role at the application of the roof sheets in different colour spectrum, e.g. increasing/decreasing of heat gains, building cooling etc. The research results proved that. The treatment of the aluminium roof sheets surface is another significant factor. The significant difference between smooth and embossed surface was found, namely $21.8 \%$ SCE. The influence was not proved at SCI.

The obtained results allow assembling a certain order of colours of the roof sheets in their ability to reflect solar radiation and thereby reduce the heat gain of the roof. The research proved that the colour tints RAL $9010 \mathrm{M}$ $\left(\mathrm{SCE} \mathrm{L}^{*}=90.1 \pm 0.1, \mathrm{SCI} \mathrm{L}^{*}=91.6 \pm 0.1\right)$ and $\mathrm{RAL}$ $9010 \mathrm{~L}\left(\mathrm{SCE} \mathrm{L}^{*}=89.9 \pm 0.1, \mathrm{SCI} \mathrm{L}^{*}=91.4 \pm 0.0\right)$ showed the best performance in this respect. In contrast, the lowest lightness value was measured for black RAL 9005 (SCE L* $=10.4 \pm 0.4,\left(\mathrm{SCI} \mathrm{L}^{*}=25.6 \pm 0.1\right)$. The colour tint RAL 9005 is the less suitable in terms of the roof sheets, which is able to effectively reflect the solar radiation and thereby reduce the heat gain of the roof.

The identification of CIELAB colours can be very useful for effective usage of the roof sheets in terms of reflecting solar radiation and thereby reducing the heat gain of the roof thanks to right choice of the colour tint.

It was proved by surface roughness measuring that the colour tint influences also the resultant surface roughness, i.e. parameters $\mathrm{Ra}$ a Rz.

\section{Acknowledgement}

Supported by Internal grant agency of Faculty of Engineering, Czech University of Life Sciences Prague (31140/1312/313108). Authors also thank for the support to the significant Czech producer and supplier of aluminium roof sheets - firm KERAMET ltd., Pod Třešněmi 616/9, 15400 Praha 5.

\section{References}

[1] ONG, K. S. (2011). Temperature reduction in attic and ceiling via insulation of several passive roof designs. In: Energy Conversion and Management, Vol. 52, pp. 2405-2411.

[2] FILHOA, J. P. B., SANTOS, T. V. O. (2014), Thermal analysis of roofs with thermal insulation layer and reflective coatings in subtropical and equatorial climate regions in Brazil. In: Energy and Buildings, Vol. 84, pp. 466-474.

[3] RAMAMURTHYA, P., SUN, T., RULED, K., BOU-ZEIDB, E. (2015). The joint influence of albedo and insulation on roof performance: An observational study. In: Energy and Buildings, Vol. 93, pp. 249-258.

[4] FOSSATI, M., SCALCO, V., A., LINCZUK, V.,C., C., LAMBERTS, R. (2016). Building energy efficiency: An overview of the Brazilian 
residential labelling scheme. In: Renewable and Sustainable Energy Reviews, Vol. 65, pp. 12161231.

[5] TUBELOA, R., RODRIGUESA, L., GILlOTTA, M., SOARESB, J., C., G. (2018). Cost-effective envelope optimisation for social housing in Brazil's moderate climates zones. In: Building and Environment, Vol. 133, pp. 213227.

[6] YEW, M. C., YEW, M. K., SAW, L. H., NG, T. C., CHEN, K. P., RAJKUMAR, D., BEH, J. H. (2018). Experimental analysis on the active and passive cool roof systems for industrial buildings in Malaysia. In: Journal of Building Engineering, Vol. 19, pp. 134-141.

[7] KOLASA, T., ROYSETA, A., GRANDCOLASB, M., TEN CATEC, M., LACAUD, A. (2019). Cool coatings with high near infrared transmittance for coil coated aluminium. In: Solar Energy Materials and Solar Cells, Vol. 196, pp. 94-104.

[8] WU, Y., KRISHNAN, P., MIN-HONG ZHANG, M. H., YU, L. E. (2018). Using photocatalytic coating to maintain solar reflectance and lower cooling energy consumption of buildings. In: Energy \& Buildings, Vol. 164, pp. 176-186.

[9] LEVINSON, R., CHEN, S., FERRARI, C., BERDAHL, P., SLACK, J. (2017). Methods and instrumentation to measure the effective solar reflectance of fluorescent cool surfaces. In: Energy and Buildings, Vol. 152, pp. 752-765.
[10] ADENIYI, I.F., OLABANJI, I.O. (2005). The physico-chemical and bacteriological quality of rainwater collected over different roofing materials in Ile-Ife, southwestern Nigeria. In: Chemistry and Ecology, Vol. 21, pp. 149-166.

[11] VIVAR, M., FUENTES, J., CASTRO, J., GARCIA-PACHECO, R. (2015). Effect of common rooftop materials as support base for solar disinfection (SODIS) in rural areas under temperate climates. In: Solar Energy, Vol. 115, pp. 204-216.

[12] MICHNA, Š., HREN, I., SVOBODOVA, J. (2019). The research of the effect of high Fe content on AlSi9NiCuMg0.5 alloy. In: Manufacturing technology, Vol. 19, No. 1, pp 107-113.

[13] HODINÁř, L., SVOBODOVA, J., HREN, I., CAIS, J., MICHNA, Š. (2019). The manganese influence on the AlSi12 alloy alfinal bath mechanical properties change. In: Manufacturing technology, Vol. 19, No. 1, pp 54-63.

[14] MICHNA, Š., NÁPRSTKOVA, N., KLIMECKA-TATAR, D. (2015). Research the causes of surface stains after eloxal coating for the profile from the AlMgSi alloy using substructural analysis. In: Manufacturing technology, Vol. 15, No. 4, pp. 620-624.

[15] SVOBODOVA, J., CAIS, J., MICHNA ড̌., BRUHA, M. (2013). Research of corrosion properties of Al-Si alloys antimony alloyed. In: Manufacturing technology, Vol. 13, No. 3, pp 404-409. 